\title{
The royal consecration ordines of the Pontifical of Sens from a new perspective
}

\section{Shane Bobrycki}

\section{(2) OpenEdition}

1 Journals

\section{Édition électronique}

URL : https://journals.openedition.org/cem/11080

DOI : 10.4000/cem.11080

ISSN : 1954-3093

Éditeur

Centre d'études médiévales Saint-Germain d'Auxerre

\section{Édition imprimée}

Date de publication : 15 août 2009

Pagination : 131-142

ISSN : 1623-5770

\section{Référence électronique}

Shane Bobrycki, «The royal consecration ordines of the Pontifical of Sens from a new perspective », Bulletin du centre d'études médiévales d'Auxerre | BUCEMA [En ligne], 13 | 2009, mis en ligne le 04 septembre 2009, consulté le 22 septembre 2022. URL : http://journals.openedition.org/ cem/11080 ; DOI : https://doi.org/10.4000/cem.11080

Ce document a été généré automatiquement le 22 septembre 2022.

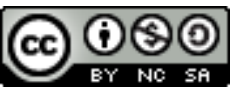

Creative Commons - Attribution - Pas d'Utilisation Commerciale - Partage dans les Mêmes Conditions 4.0 International - CC BY-NC-SA 4.0

https://creativecommons.org/licenses/by-nc-sa/4.0/ 


\title{
The royal consecration ordines of the Pontifical of Sens from a new perspective
}

\author{
Shane Bobrycki
}

1 Historians have long turned to royal consecration ordines for insights about early medieval kingship ${ }^{1}$. Christian royal consecrations go back into late antiquity, but ordines for these rites first emerged in Carolingian Europe, above all in ninth-century west Francia ${ }^{2}$. Generally speaking, an ordo is a liturgical text that prescribes the actions and words of celebrants during a rite ${ }^{3}$. Ordines for royal consecration are thus transcripts for that most significant of rites, a king's or queen's inauguration ${ }^{4}$. Supplemented by written or archaeological sources, ordines speak to the very essence of medieval rulership: what legitimized and constituted it ${ }^{5}$.

2 But there are problems with traditional Ordines-Studien. Historians often study ordines with an eye to actual ritual; Schramm tried to match each west-Frankish ordo with a specific consecration ${ }^{6}$. Yet the leap from textual description to ritual performance is dubious ${ }^{7}$. Texts, as Philippe Buc reminds us, are also « forces in the practice of power » : interpretations, not just reflections, of the world around them ${ }^{8}$. Liturgy was a common battleground for competing politics in the early middle ages, and the fight did not stop once pen hit vellum ${ }^{\text {. Actual }}$ consecrations are important (they had larger audiences than texts after all), but consecration ordines are primarily evidence for the motives, perceptions, and beliefs of their compilers, only secondarily for actual rituals.

3 A second problem with Ordines-Studien is its text-based approach. A textual purview makes sense with liturgy. From at least the eighth century, most ordines are standardised from one liturgical manuscript 
to another ${ }^{10}$. We would be nominalists indeed if we insisted that Ordo romanus 41 in one manuscript must be strictly distinguished from Ordo romanus 41 in another. Context does change meaning though sometimes more than our scholarly editions suggest ${ }^{11}$. Medievalists have long recognised that manuscripts too were « forces in the practice of power ${ }^{12}$. Just as texts interpret rituals, manuscripts interpret texts. This is particularly true with royal consecration ordines, which were not standardised across liturgical manuscripts until the late tenth century ${ }^{13}$.

4 Sometimes, we lack contemporary manuscripts. This is the case with a lost manuscript of Liège containing the ninth-century ordines of Hincmar of Reims (printed in the seventeenth century by Sirmond before the manuscript was lost) and with ordines that survive in the formulae of their textual descendents (like the Anglo-Saxon ordines excavated from the formulae of medieval French manuscripts) ${ }^{14}$. We would not want to lose such sources. But codicologically-disembodied exceptions should not define the rule. Manuscript evidence is too often ignored or distorted to fit a text-based mould. Textual assertions should not drown out codicological ones. In this paper I will shift the perspective from texts and Hincmar, to manuscripts and a new archbishopric : Sens.

5 St. Petersburg, Nat. Libr., lat. Q.v.I., no. 35 [hereafter $P$ ] is a liturgical book of 107 folios for the archbishop of Sens ${ }^{15}$. It is deluxe, with a hierarchy of scripts and extensive decorations (gold initials, purple ornaments, architectural designs, floral embellishments and birds) ${ }^{16}$. The date is probably late ninth-century ${ }^{17}$. Its contents are those of a pontifical (which united the functions of a sacramentary, libelli, and a benedictional), hence its moniker «pontifical of Sens ». Note however that pontificals were still novel in the late ninth century ${ }^{18}$. We are better off listing contents : the annual and occasional blessings and a large collection of non-eucharistic ordines.

6 In $P$, texts labelled as ordines are quite varied in content. Ordo had many meanings in early medieval Latin: «series », «description », « order», « class», « rank», « ecclesiastical order», as well as ordo in the liturgical sense ${ }^{19}$. Even liturgically, however, the word cast a wide semantic net ${ }^{20}$. Some ordines contain full texts of blessings and prayers ; others give only incipits. Some have detailed rubrics to guide the celebrant through the rite; others just list texts to be read. Sometimes, liturgical and other meanings blend into one another : in the ordines for the ordination of clerical "orders", the ordo (the liturgical text) confers (and, in some sense, represents) the ordo (the ecclesiastical rank). Most ordines in $P$ are familiar textslike the ordo for dedicating a church (Ordo romanus 41), which appears under the uncial heading ordo ad aecclesiam dedicandam at f. 35r-41r (one of the ordines romani). But innovation lurks behind the familiar in this archbishop's book. 
7 The greatest innovation of $P$ is in its royal consecration ordines. In the ritual-aimed, text-driven discipline of Ordines-Studien, these (pl.) go by the single title "Erdmann Ordo», a conflation coined by Schramm ${ }^{21}$. Some explanation : amongst historians of «coronations ${ }^{22}$, the word «Ordo» (usually capitalised) is used to describe almost any kingmaking (or often king-blessing) text, regardless of source or sourcetitle ${ }^{23}$. "Ordines » are given monikers, or enumerated, and printed together in modern editions. Specialists usually know that there is a difference between what is strictly a benedictio and what they call an "Ordo», what comes from a sacramentary and what comes from a chronicle ${ }^{24}$, but perhaps some pedantry is in order.

8 The "Erdmann Ordo » is (are ?) in fact two separate ordines and, four pages later, a «benediction» ${ }^{25}$. Not only are these «three» texts rather different in content, and, in the case of the benedictio, physically apart ; they already have their own headings in the manuscript : incipit ordo ad ordinandum regem (f. 85r-92v), incipit ordo ad ordinandam reginam (f. $92 \mathrm{v}-94 \mathrm{v})$, and item benedictio ad ordinandum regem (f. 97r-97v). Medieval liturgists were slippery enough about their own use of the term ordo that we only increase our confusion by calling two spades and a shovel a Spade. The stakes are higher still. Medieval liturgists were slippery on purpose. By ignoring how compilers changed ordines by presenting them in new ways, we ignore our evidence.

9 For instance, Schramm did not include the five prayers between the queen's ordo and the benedictio (f. 95r-96v) in what he called the «Erdmann Ordo » ${ }^{26}$. Schramm's reason for categorising these texts as a unit (and underplaying Sens initiative) was that they appeared together in Paris, Bibliothèque nationale, MS lat. 17333, a pontifical copied for Hugh the Great, bishop of Nevers (1011-1065). There, the benedictio was inserted into the king's ordo. Schramm thought that these manuscripts were unrelated ${ }^{27}$. As Jackson has shown, however, the Nevers texts were copied straight from the Sens manuscript ${ }^{28}$. Bishop Hugh may have attested his submission to Sens on a page of the queen's ordo itself ${ }^{29}$. But Jackson, although he corrects Schramm here, follows him in prioritising the "Erdmann Ordo» over $P$ at folios $85 \mathrm{r}-96 \mathrm{v}$. Jackson thus omits the five prayers between the queen's ordo and the benedictio from his "Ordo XII », declaring that they " have nothing to do with coronations ${ }^{30}$. It seems to me that «BENEDICTIO QUANDO AD BELLUM CONTRA HOSTES PROFICISCITUR», «ITEM BENEDICTIO QUANDO CONTRA PAGANOS PUGNANDUM EST », « BENEDICTIO UBI UOLUERIS » (e.g. ...Bella comprimat, famem auferat, pacem | tribuat ac inimicorum omnium insidias longe repellat Amen...), and « BENEDICTIO PRO QUALIBET TRIBULATIONE » are here for a reason. They have everything to do with the relationship between an archbishop and a king ( IN NAUITATE SANCTE MARIE » is slightly less obvious, though it could pertain to the queen), if they do not say much about «coronations». But « coronation » is just a small part of what this manuscript presents. We cannot ignore $P$ 's presentation of rulership rites as the passive 
recording of evidence for coronation rituals. $A u$ contraire, $P$ 's presentational strategies - even the very inclusion of these texts in this manuscript - are more significant political assertions than anything in the texts themselves.

This is not to discount expert examination of these texts. Schramm, Bouman, Bautier, Jackson, and Nelson among others have ably examined these texts' genealogies and ideological significance ${ }^{31}$. To summarise : in the king's ordo, we have a petition/response text in which the king swears to protect the church upon a request from the bishops, the anointing and blessing of the king with several prayers, and the king's investment with sword, crown, ring, scepter, and staff, completed by a special mass. In the queen's ordo, we have an anointing, the investment of crown and ring, and a mass. The five prayers have to do with tribulations (in language that seems closely linked to the role of a king as a protector against tribulations), and Mary (which may echo the queen's role). The benedictio is a second set of investment blessings for the same regalia as in the king's ordo, in the same order, with slightly different texts (which may be why the Nevers book inserted them into the king's ordo).

11 The picture of kingship gleaned from these texts is resolutely Carolingian. The ordines betoken a conception of rulership common in early medieval ecclesiastical circles, in which kingship (later queenship) is an office or ministry bestowed by a prelate ${ }^{32}$. This was part of a wider political metaphor : society as ecclesia, in which each ordo (« rank ») of society has its own ministry (authority as well as obligations) including the king ${ }^{33}$. This view of kingship did not always reflect politics as they were practiced (Ullmann overemphasised its political effectiveness) ${ }^{34}$. But it was consistently argued. The prayer texts of our ordines are typical in their presentation of ministerial duties : the king must protect the church, maintain justice, uphold the orders of society, and fight against those who threaten any of his charges. The queen must maintain dignity, to combat heresy and paganism, and support the church.

12 These are not just familiar claims, they are - in the case of the king's ordo - familiar texts. This whole ordo is based upon consecration texts for earlier Carolingian kings, especially those of Louis the Stammerer. One can, for instance, trace a rough genealogy of the petition/response in the king's ordo straight through similar texts that have survived for Odo (888), Carloman (882), and Louis the Stammerer (878) ${ }^{35}$. In the lost Liège manuscript, Louis the Stammerer promises to uphold a chapter from the capitulary of Quierzy in 877 (of his father Charles the Bald) ${ }^{36}$. This same promise, updated to suit the times (Charles as father, or grandfather, depending on who is swearing), was repeated at several consecrations in the late ninth century ${ }^{37}$. P's ordo preserves the text, but loses the particular references to Charles and Quierzy.We cannot be certain as to when this happened, since it could have been as early as 878 , but we might posit a fuzzy terminus post quem of $882 \mathrm{P}$, for it was 
in that year that Carloman made the last-recorded reference to Quierzy in his promissio ${ }^{38}$.

13 The reason we cannot be surer is that the king's ordo is stripped of localising references. This is significant. Earlier west Frankish consecration ordines, like those of Hincmar, are, in keeping with the ad hoc nature of contemporary consecrations, more like memoranda than transpersonal texts ${ }^{39}$. Names and details abound. P's king's ordo is the finale of a slow semantic legerdemain. Hincmar and other compilers of late ninth-century Carolingian ordines used «ordo » both in the sense of a liturgical text and of an « arrangement » or « process » (how suchand-such a king was consecrated), giving their texts a liturgical ring. The compiler of $P$ took this transformation a step further : by stripping particular references, he transformed the meaning of «ordo » even though his text was derivative. In the petition/response, he kept the cachet of old words, but de-personalised, de-Carolingified them by removing references to Charles the Bald and Quierzy. By so doing, he stressed the transpersonality of royal ordination, an ordo like any other in this large pontifical ${ }^{40}$.

14 With the queen's ordo, the road to transpersonalisation was different. The queen's ordo and the king's ordo are dissimilar texts. The queen's ordo is rubric-heavy, while the king's merely gives titles. Its text, as Nelson has shown, is also firmly ministerial - queenship is no accident of marriage here, but a state instituted (instituitur) or ordained (ordinare) by an archbishop ${ }^{41}$. Unlike the king's ordo, it has no clear source. While the text borrows from the ordination ritual for an abbess, as Nelson points out, it is not a massive verbatim copy-job like the king's ord $^{42}$. The compositional process thus appears to have been the writing of a novel text in a standard liturgical vocabulary, not the recontextualisation of older texts.

15 In fact, the queen's ordo may have been composed (in the conventional sense) by someone at Sens ${ }^{43}$. The titles archiepiscopus (93r), pontifex (93r), and summus episcoporum (93r) for the celebrant show that the text was written with an archbishop in mind. Furthermore, this section of $P$ later became a locus for sénonois assertions about archiepiscopal authority. In the tenth and early eleventh centuries, subscriptions of suffragan bishops were entered into this book here (including Hugh of Nevers's), as was a passage from Hraban Maur's de institutione clericorum on the authority of the archiepiscopal pallium $(94 \mathrm{v})$. The ordo ad ordinandam reginam was clearly linked in sénonois minds to their archbishop's authority.

16 What is lost in the conflation «Erdmann Ordo » is that these different texts were juxtaposed on purpose by the compilers of $P$. In spite of their compositional differences, they are placed side by side with almost mirroring names. By accepting their unity as a given, we miss the magic. The king's ordo legitimises an novel production (the queen's ordo) thanks to its conservative, traditional texts (but stripped of their particulars). Reciprocally, the queen's ordo, composed ex nihilo as a 
declaration of archiespiscopal authority over the bestowal of transpersonal rulership (or, as Nelson points out, an assertion of authority in a political world where legitimate queenship was increasingly important ${ }^{44}$ ), completes the transformation of the historicising sources of the king's ordo into a transpersonal domain. This is just the tip of the iceberg. The whole manuscript serves to reinforce the idea that these royal ordines are ordines in the transpersonal, liturgical sense - just as repeatable (and independent of the peculiar bloodline or qualities of any given king or queen) as the ordo for dedicating a church or for ordaining a priest. How ? St. Petersburg Q.v.I., no. 35, like most deluxe Frankish liturgical manuscripts, uses a hierarchy of scripts : large capitals for the first word of every text, uncial headings, rustic capitals at the start of new clauses and sometimes as rubrics. In the early middle ages, such a hierarchy was a recognizable canvas for the painting of legitimacy by association ${ }^{45}$. In our manuscript, only important texts are singled out for decoration : the litanies of the saints at the opening of the book, the benedictions for the most important holidays, the frontispiece to the section for the ordination of clerics, and the striking frontispiece for the ordination of the king - depicting a crown hanging beneath an arch bordered by two birds.

Moreover, similar material is similarly decorated: opening sections (f. 8r, 10r, 19v); the main headings for penitential material (f. 5r), clerical ordination (f. 9v), and royal ordination (f. 85r); litanies (f. $5 \mathrm{v}-7 \mathrm{v}$ ) ; analogous prayers (e.g. f. 19v and f. 93r) ; abbreviations near the start of anointing rituals (e.g. f. 20v and 86r) ; major festivals (f. 59r, $64 \mathrm{r}, 67 \mathrm{v}$ ) ; transitions and other opening texts (e.g. f. 15v, 23v, 90v). There is a strong sense of codicological order to raise the profile of such juxtapositions. Each quire is numbered, and large decorations occur at the beginnings (f. $5 r$ : quire I, $85 r$ : quire XII) or ends (f. $20 \mathrm{v}$ : quire QII) of major quires. In the case of fol. 85r, the first of quire XII (entirely given to the king's ordo), the last page of the preceding quire, fol. $84 \mathrm{v}$ (Q XI), is executed in a scrunched minuscule, compressed so as not to run over into the next quire. This allows the quire containing the king's ordo to open grandly, in the arch mentioned, in gold letters over a purple backdrop : INCIPIT ORDO AD ORDINDANDUM REGEM. Royal ordination is literally depicted as one of the most important liturgical functions of the archbishop for whom the book is constructed, on par with penitence, clerical ordination (including episcopal), and the celebration of Easter and Pentecost - and related to aspects of all the above. Thus, by codicological as well as textual decree, our manuscript promotes a transpersonal view of kingship and queenship, stressing the authority of the archbishop in bestowing these ordines.

What is the historical significance of this ? We return to our fuzzy terminus post quem in the 880s. At the end of the ninth century, a series of Carolingian deaths deprived the Frankish world of legitimate male Carolingians. Charles the Fat was the last legitimate male 
Carolingian to rule as sole emperor, but he was deposed by his illegitimate nephew Arnulf in 887, dying in $888^{46}$. Then, as vividly described by contemporary annalists, many claimants dissolved the empire into little regna of their own ${ }^{47}$. Not all were non-Carolingians. None were both legitimate and male-line, however, and many, including Odo, elected as king in west Francia, had no Carolingian blood at all. In the ninth century, legitimate, male-line Carolingian blood had become a significant symbolic commodity. When Boso tried to ride to kingship in Provence in the 870s on the legitimacy of his Carolingian wife, an elaborate consecration, and his own great power, he was defeated by all four then-ruling Carolingians ${ }^{48}$. In 888, things were different : the only legitimate, male Carolingian was a child. Norms shifted, as Michel Sot and Régine le Jan have argued, towards military prowess, though episcopal ordination became a sine qua non ${ }^{49}$. Odo was consecrated by none other than Archbishop Walter of Sens ${ }^{50}$. Now, the Carolingian Charles the Simple, child in 888, came back; he received consecration from Archbishop Fulk of Reims and opposed Odo as the legitimate king ${ }^{51}$. He did not prevail against Odo but he did become king after Odo's death. In 922, however, he was himself resisted by Robert of Neustria (Odo's brother), who was himself consecrated, again by Walter of Sens. When Robert died in the battle of Soissons against Charles, the archbishop of Sens now consecrated Robert's son-in-law, Radulf, as king. Nelson has already connected the politics of this period with $P$ 's ordines. Royal wives were a major source of legitimacy for Radulf, neither Robertian nor Carolingian himself, but married to a wife who was both ${ }^{52}$.

21 Petersburg Q.v.I., no. 35 and its consecration ordines may be read as Archbishop Walter's move in this reshuffling of norms, the defence he put up against legitimist (rémois) arguments of royal authority, and for transpersonal rulership. The manuscript itself was an assertion of this archiepiscopal authority in the post-Carolingian world. This is true whether or not, as is wholly possible, St. Petersburg Q.v.I., no. 35 was toted through west Francia and used for the consecrations of Odo, Robert, or Radulf and/or their wives ${ }^{53}$. This is true whether or not the texts of this manuscript were influential in later Frankish and AngloSaxon traditions ${ }^{54}$.

To put it a different way : "After the death [of Charles the Fat], the kingdoms which had been obedient to his authority, as though they lacked a legitimate heir, were dissolved into parts from their former unity. Now they did not wait for a natural lord, but each one decided to make a king for itself out of its own guts (unumquodque de suis visceribus regem sibi creari disponit) $\gg{ }^{55}$. Thus, Regino of Prüm ${ }^{56}$. For a hundred and fifty years, kingship had been associated with the legitimate males of the Carolingian family. Perhaps some had always doubted this association; others had certainly sought to challenge or mitigate it in the long history of Carolingian kingship. But 888 changed the game. Elites now had to ask themselves a question : how do you 
make a king from your own guts ? More to the point, how do you make a king who will serve in your own interests? For the archbishop of Sens, the answer to both was obvious : use a book.

\section{NOTES}

1. R. A.JACKSON, Ordines Coronationis Franciae. Texts and ordines for the coronation of Frankish and French kings and queens in the middle ages, t.1, Philadelphia, 1995 [hereafter, JACKSON, OCF], has a good overview of the history of ordinesstudies with bibliography, esp. p. 4-6. Key starting points are P. E. SCHRAMM, « Die Krönung bei der Westfranken und den Angelsachsen von 878 bis um $1000 »$, Zeitschrift für Rechsgeschichte, 23 (1934), p.117-242; ID., "Ordines-Studien II : Die Krönung bei den Westfranken und den Franzosen", Archiv für Urkundenforschung, 15 (1938), p. 3-55, p. 279-286; ID., Kaiser, Könige, und Papste : gesammelte Aufsätze zur Geschichte des Mittelalters, 4 vol., Stuttgart, 1968-1971, t. 2 ; с. A. Bouman, Sacring and crowning: the development of the Latin ritual for the anointing of kings and the coronation of an emperor before the eleventh century, Groningen, 1957 ; J. NELSON « Ritual and reality in the early medieval ordines ", in EAD., Politics and ritual in early medieval Europe, London, 1986, p. 329-339.

2. For overviews see R.-H.BAUTIER, «Sacres et couronnements sous les Carolingiens et les premiers Capétiens : recherches sur la genèse du sacre royal français ", Annuaire-bulletin de la Société de l'histoire de France (1989), p.17-56 (reprinted in ID., Recherches sur l'histoire de la France médiévale, London, 1991, item II), supplemented (for queens) by J. NELSON, "Early Medieval Rites of Queen-Making and the Shaping of Medieval Queenship ", in A. J. DUGGAN, ed., Queens and queenship in medieval Europe, Woodbridge, 1997, 301-315 (reprinted in J. NELSON, Rulers and ruling families in early medieval Europe, Aldershot, 1999, item XV).

3. c. vogel, Medieval liturgy. An introduction to the sources, trans. W. STOREY and N. RASMUSSEN, Spoleto, 1981, p. 135-139.

4. J. FLECKENSTEIN, «Rex Canonicus : Über Entstehung und Bedeutung des mittelalterlichen Königskanonikates", in ID., Ordnungen und formende Kräfte des Mittelalters : Ausgewählte Beiträge, Göttingen, 1989, p. 197.

5. For Frankish inauguration rituals, see J. NELSON, « Inauguration rituals », in EAD., Politics and ritual..., op. cit., p. 283-308 (originally published in P. H. SAWYER and I. N. WOOD, Early medieval kingship, Leeds, 1977, p.50-71) and EAD., "The lord's anointed and the people's choice: Carolingian royal ritual ", in EAD., The Frankish World, 750-900, London, 1996, p. 99-132.

6. P. Е. SCHRAMM, « Ordines-Studien II... », op. cit., p. 3.

7. $\mathrm{Ph}$. Buc, The dangers of ritual : between early medieval texts and social scientific theory, Princeton, 2001; ID., "Rituel politique et imaginaire politique ", Revue historique, 305 (2001), p. 843-883; G. KOzIoL, "The dangers of polemic: is ritual still an interesting topic of historical study? ", Early Medieval Europe, 11 (2002), p. 367-388 offers a rejoinder; for an excellent discussion of the ritual debate, see C. PösseL, "Symbolic communication and the negotiation of power at Carolingian regnal assemblies, 814-840», 
unpublished PhD thesis, University of Cambridge (2004), p. 16-32 and now Ph. BUc, « The monster and the critics : a ritual reply ", Early Medieval Europe, 15 (2007), p. 441-452.

8. Ph. Buc, The dangers..., ibid., p. 259.

9. M. мссовміск, "The liturgy of war in the early middle ages: crisis, litanies, and the Carolingian monarchy », Viator, 15 (1984), p. 1-23.

10. C. vogel, Medieval liturgy..., op. cit., p. 191-193; M. ANDRIEU, Les OrdinesRomani $d u$ haut Moyen Âge,4 vol., Leuven, 1956.

11. R. MCKITTERICK,Perceptions of the past in the early middle ages, Notre-Dame, 2006, p. 1-5. For Ordo romani 41, see M. ANDRIEU, Les OrdinesRomani..., op. cit., $339 \mathrm{ff}$.

12. See R. мскітTеRICK, Perceptions of the past..., ibid.; EAD., The Carolingians and the written word, Cambridge, 1989; and EAD., History and memory in the Carolingian World, Cambridge, 2004.

13. J. NELSON, «Early Medieval Rites... », op. cit., p. 310, n. 50.

14. On the Liège collection, see R. JACKSON, « Who wrote Hincmar's Ordines ? », Viator, 25 (1994), p. 31-52 and ID., OCF, p. 15-18 and 24-26, texts at p. 73-123; J. NELSON, "Kingship, Law and Liturgy in the Political Thought of Hincmar of Reims ", English Historical Review, 92 (1977), p. 241-279 ; J. NELSON, « Early Medieval Rites... », ibid., p. 301, n. 2. For the Anglo-Saxon ordines see EAD., Ritual and politics..., op. cit., p. 341-360 and 361-374, and now EAD., « The First Use of the Second Anglo-Saxon Ordo", in J. BARRow and A. WAREHAM, eds., Myth, Rulership, Church and Charters : essays in honour of Nicholas Brooks, Aldershot, 2008, p. 117-126.

15. N. RASMUSSEN, Les pontificaux du haut Moyen Âge : genèse du livre de l'évêque, Leuven, 1998, p. 89-135 has a full description; A. STAERK, Les manuscrits latins du Ve au XIIIe siècle conservés à la Bibliothèque impériale de Saint-Pétersbourg: description, textes inédits, reproductions autotypiques, St.Petersburg, 1910, t.1, p. 151-173 has a transcription, but it suffers from error and inconsistency; for descriptions see G. LOBRICHON, « Nouvelles recherches sur le rituel pontifical de Sens au IXe siècle ", Bulletin de la Société nationale des antiquaires de France (1992), p. 191-200 ; c. voGEL, Medieval liturgy..., op. cit., p.225-229; Lobrichon is working on a long-needed edition of this manuscript. I examined the microfiche at the Isham Memorial Library, Harvard University, and should like to extend my thanks to Dr Sarah Adams.

16. G. LOBRICHON, « Nouvelles recherches... », op. cit., p. 192.

17. Bischoff dated it to the third quarter of the ninth century, but it is likely that an oldfashioned hand might be used in a liturgical context. See N. RASMUSSEN, Les pontificaux..., op. cit., p. 93, n. 23. The dating remains disputed however, with Lobrichon arguing for an earlier date. See G. LOBRICHON, « Nouvelles recherches... », ibid.

18. For this see Y. HEN, The royal patronage of liturgy in Frankish Gaul, London, 2001, p. 148-154.

19. Cf. F. BLATT, Novum Glossarium Mediae Latinitatis ab anno DCCC usque ad annum MCC, O-Ocyter, Hafniae, 1975, p. 731-772. See also ordinatio at p. 696-708. DU CANGE and J. F. NIERMEYER also run several pages in their reference books.

20. c. vogel, Medieval liturgy..., op. cit., p. 135-139.

21. P. е. schramm, Kaiser, Könige, und Papste..., op. cit., t.2, p.159-165 and 216-221; Cf. c. A. Bouman, Sacring and crowning..., op. cit., p. 168-169.

22. Coronation was only a part of early medieval consecration, but the synecdoche is widely used.

23. JACKSON, $O C F$, p. 2-3.

24. J. NELSON, « The First Use... », op. cit., p. 177, n. 1. ; JACKSON, OCF, p. 2, n. 4. 
25. Beware the ontological confusion of JACKSON, OCF, p. 144 : "The two [that is, (1) the ordo ad ordinandum regem and the ordo ad ordinandam reginam as anit and (2) the benedictio] are actually separate ordines, but because in manuscript $B$ the second set was inserted into the first, between nos. 14 and 15, I have chosen to treat them as Ordo XIIIA and XIIIB. »

26. Though he chose the name because Carl Erdmann had written about (four of) these prayers : C. ERDMANN, "Der Heidenkrieg in der Liturgie", Mitteilungen des Instituts für österreichische Geschichtsforschung, 46 (1932), p. 129-142.

27. Р. є. schramm, Kaiser, Könige, und Papste..., op. cit., t. 2, p. 217.

28. JACKSON, $O C F$, p. 144-145.

29. Among the suffragan submissions written in this part of the manuscript, two Hughs attest their submission to Sens at the top and bottom of f. 93v (in the middle of the queen's ordo).

30. JACKSON, $O C F$, p. 143-144.

31. P. е. schramm, Kaiser, Könige, und Papste..., op. cit., t. 2, p. 159-165 and 216-221 ; ID., "Ordines-Studien II...", op. cit., p. 17-18 and 279-286; c. A. BOUMAN, Sacring and crowning..., op. cit., p.15-17, 129-130 and 155-156; R.-H.BAUTIER, "Sacres et couronnements...», op. cit., p. 47-50 ; JACKSON, OCF, p. 26-27 and 142-153 ; J. NELSON, " Early Medieval Rites... », op. cit., p. 309-311.

32. H.X. ARQUillière, L'augustinianisme politique: essai sur la formation des théories politiques du Moyen Âge, 2nd edn., Paris, 1955, p. 124 ; E.J. BuschmanN, «Ministerium Dei - Idoneitas», Historisches Jahrbuch der Görresgesellschaft, 82 (1963), p.70-102; H. H. ANTON, Fürstenspiegel und Herrscherethos in der Karolingerzeit, Bonn, 1968, p. 404-419 ; J. NELSON, "National synods, kingship as office, and royal anointing: an early medieval syndrome ", in EAD., Politics and ritual..., op. cit., p. 239-258.

33. M. DE JONG, "Ecclesia and the early medieval polity », in S. AIRLIE, W. POHL, and H. REIMITZ, eds., Staat im frühen Mittelalter, Vienna, 2006 (Forschungen zur Geschichte des Mittelalters, 11), p.113-132; EAD., "The empire as ecclesia: Hrabanus Maurus and biblical historia for rulers ", in Y. HEN and M. INNES, eds., The uses of the past in the early Middle Ages, Cambridge, 2000, p. 191-226; M. DE JONG, « Sacrum palatium et ecclesia. L'autorité religieuse royal sous les Carolingiens (790-840) ", Annales, 58 (2003), p. 1243-1269.

34. J. NELSON, "The lord's anointed and the people's choice... ", op. cit., 105-108; W. ULLMANN, The Carolingian renaissance and the idea of kingship, London, 1969, p. 86-96 and ID., Principles of government and politics in the middle ages, 4th edn, London, 1978, p. 117.

35. JACKSON, OCF, p. 110-138.

36. JACKSON, $O C F$, p. 120.

37. JACKSON, $O C F$, p. 132.

38. See JACKSON, $O C F$, p. 132.

39. JACKSON, $O C F$, p. 29.

40. Cf. J. NELSON, "Early Medieval Rites...", op. cit., p. 309, n. 42. This would represent the moment at which a contemporary asserted the transpersonality of ordines.

41. J. NELSON, «Early Medieval Rites... », ibid., p. 308-309 ; p. 306-308 for the Hincmarian attitude.

42. J. NELSON, « Early Medieval Rites... », ibid., p. 309.

43. Cf. J. NELSON, «Early Medieval Rites... », ibid., p. 309-311; For « composition » of ordines, see Jackson, « Who wrote Hincmar's Ordines?».

44. J. NELSON, « Early Medieval Rites... », ibid., p. 311. 
45. R. MCKITTERICK, " Text and image in the Carolingian world », in R. MCKITTERICK, ed., The uses of literacy in early medieval Europe, Cambridge, 1990, p.297-318 (reprinted in R. MCKITTERICK, Books, Scribes, and Learning, VI-IX centuries, Aldershot, 1994, item VII).

46. The following is indebted to S. MACLEAN, Kingship and politics in the late ninth century: Charles the Fat and the end of the Carolingian empire, Cambridge, 2003 ; see also S. AIRLIE, « Les élites en 888 et après, ou comment pense-t-on la crise carolingienne ? ", in F. BOUgARD, L. FELLER and R. Le JAN (eds.), Les élites au haut Moyen Âge: crises et renouvellements, Turnhout, 2006, p. 425-437;R. МСКITTERICK, The Frankish kingdoms under the Carolingians, 751-987, London, 1983, p. 262-266 remains a useful introduction to these events.

47. See below.

48. S. AIRLIE, «The nearly men : Boso of Vienne and Arnulf of Bavaria ", in A. DUGAN (ed.), Nobles and Nobility in medieval Europe : concepts, origins, transformations, Woodbridge, 2000, p. 25-41 ; S. MACLEAN, "The Carolingian Response to the Revolt of Boso, 879-87 ", Early Medieval Europe, 10 (2001), p. 21-48; see J. FRIED, «Boso von Vienne oder Ludwig der Stammler ? Der Kaiserkandidat Johanns VIII », Deutsches Archiv, 32 (1976), p. 193-208.

49. R. LE JAN, «Le royaume franc vers 900 : un pouvoir en mutation? ", in P. BAUDUIN (éd.), Les fondations scandinaves en Occident et les débuts du duché de Normandie, Caen, 2005, p. 83-95 ; M. SoT, « Hérédité royale et pouvoir sacré avant 987 », Annales ESC, 43 (1988), p. 705-733 ; J. DHONDT, "Élection et hérédité sous les Carolingiens et les premiers Capétiens ", Revue belge de philologie et d'histoire, 18 (1939), p. 913-953 remains useful.

50. No good survey of Sens exists for the period. See R. MCKITTERICK, « The Carolingian kings and the see of Rheims, 882-987 ", in Frankish kings and culture, Aldershot, 1995, IV, p. 228-249 ; A. FLICHE, «La primatie des Gaules depuis l'époque carolingienne jusqu'à la fin de la querelle des investitures (876-1121)», Revue historique, 173 (1934), p. 329-342.

51. S. AIRLIE, "Les élites en 888 et après... ", op. cit.; see also G. KozIoL, "Charles the Simple, Robert of Neustria, and the vexilla of Saint-Denis ", Early Medieval Europe, 14 (2006), p. 355-390 ; ID., " Is Robert I in hell ? The diploma for Saint-Denis and the mind of a rebel king (Jan. 25, 923) ", Early Medieval Europe, 14 (2006), p. 233-263 and ID., The footsteps of kings : West Frankish royal diplomas and their stories (840-987), forthcoming.

52. J. NELSON, « Early Medieval Rites... », op. cit., p. 311.

53. See J. NELSON, «Early Medieval Rites... », ibid., p. 310-311 for a tentative solution.

54. JACKSON, $O C F$, p. 26-27.

55. REGINO OF PRÜM, Chronicon, s.a. 888, in F. KURZE, ed., Reginonis abbatis prumiensis Chronicon cum continuatione treverensi, Hanover, 1890 (MGH Scriptores rerum germanicarum, 50), p. 129 ; for background see S. AIRLIE, " "Sad stories of the death of kings" : narrative patterns and structures of authority in Regino of Prüm's Chronicon », in E. M. TYLER and R. BALZARETTI (eds.), Narrative and history in the early medieval west, Turnhout, 2006, p. 105-131; s. MacLean has a translation forthcoming.

56. Overquoted perhaps. An underappreciated commentator is the Panegyric of Berengar (Gesta Berengarii, though the title in the original MS is in Greek), which reads, «Ille [Charles the Fat] quidem sic astra subit ; miseranda cupido / Sed populos pervasit agens, qui limite lato / Unius imperio soliti concurrere, plures / Ut mirentur abhinc diversa per arva tirannos, /Et sibi queque legat proprium gens » ("Thus he [Charles the Fat] ascends to the heavens ; but a lamentable desire, raging, spread through the people, who had been accustomed to march forth under the rule of one, so that henceforth they lusted after many tyrants through the diverse lands, and each people chose one for itself »), MGHPoetae 4.1, p. 359. 
INDEX

Mots-clés : pontifical, consécration

Index géographique : France/Sens

\section{AUTEUR}

\section{SHANE BOBRYCKI}

Shane Bobrycki est candidat au doctorat à l'université de Cambridge, où il étudie l'histoire du haut Moyen Âge. Il a obtenu son M. Phil. à Cambridge en 2008 et son B.A. en histoire à Williams College en 2007. Il s'intéresse à la royauté à la fin de l'époque carolingienne. 